\title{
Expression of Copper/Zinc Superoxide Dismutase and Glutathione Peroxidase in Organs of Developing Mouse Embryos, Fetuses, and Neonates
}

\author{
JUDY B. DE HAAN, MARTIN J. TYMMS, FRANCESCA CRISTIANO, AND ISMAIL KOLA \\ Molecular Embryology and Birth Defects Lab. Centre for Early. Human Development. Institute for Reproduction \\ and Development, Monash University: Cla!ton. I'ictoria 3168. Australia
}

\begin{abstract}
The rise in antioxidant enzyme activity in the lungs of late-gestation fetuses is thought to be caused by the preparation of the pulmonary antioxidant system for birth. However, recent data have shown that such a rise also occurs in the livers of late-gestation fetuses. Consequently, this surge cannot solely be ascribed to the preparation of the pulmonary antioxidant system for birth. In this study we examine the expression of copper/zinc superoxide dismutase (Sod1) and glutathione peroxidase (Gpx1) in various organs of late-gestational mouse fetuses. Furthermore, we compare the expression of these genes in organs of fetuses, neonates, and adult mice. These studies were carried out to investigate whether the change in mRNA levels for these two genes is related to a developmental change in oxidant stress. Our data demonstrate that an increase in both Sod 1 and Gpx1 mRNA occurs in lungs and livers of late-gestational mouse fetuses. The brain demonstrates an increase in Sod 1 expression at or around the time of birth, the kidney shows an elevation in Gpx1 mRNA levels, and the heart fails to demonstrate a surge in both Sod1 and Gpx1 mRNA levels. Our data show that the liver is the organ with the highest levels of Sod1 and Gpx1 mRNA in embryos and neonates (immediately after birth). In the adult, the liver has the highest levels of Sod 1 mRNA and the spleen the highest level of Gpx1 mRNA. These data suggest that the levels of Sod1 and Gpx1 mRNA are unrelated to oxygen consumption and to oxygen tension exposure of individual organs and do not necessarily appear to occur in the lung solely in preparation for birth. The reasons for the increase in antioxidant enzyme(s) mRNA levels in late gestation are more complex and may involve other factors. (Pediatr Res 35: 188-196, 1994)
\end{abstract}

\section{Abbreviations}

Sod, superoxide dismutase

Sod1, copper/zinc superoxide dismutase

Gpx1, glutathione peroxidase

Aerobic cells are exposed to harmful reactive oxygen species that are generated during the process of oxidative metabolism. These reactive oxygen species include the superoxide radical,

Received January 25, 1993; accepted September 15, 1993

Correspondence and reprint requests: Dr. Ismail Kola, Molecular Embryology and Birth Defects Lab, Centre for Early Human Development. Monash Medical Centre, 246 Clayton Rd., Clayton, Victoria 3168. Australia.

Supported by a Victorian Health Promotion Foundation Program Grant to I.K. J.B.D.H. was supported by a Monash University Postgraduate Scholarship. hydrogen peroxide, and the highly reactive hydroxyl radical, which will interact with macromolecules in their immediate vicinity causing damage to lipids and DNA (1). Cells have developed antioxidant defenses to protect against such noxious moieties. Important are the scavenging enzymes such as Sod (EC 1.15.1.1), Gpx1 (EC 1.11.1.9), and catalase (EC 1.11.1.6). Eukaryotic cells have a secretory or extracellular form of Sod and two kinds of intracellular Sod enzymes: a ubiquitous predominant copper/zinc-containing enzyme $(\operatorname{Sod} 1)$, which is mainly cytosolic in location (2), and a manganese-containing enzyme (Sod2), which is found in the mitochondria (3). Sod catalyzes the conversion of the superoxide radical to hydrogen peroxide. Hydrogen peroxide in turn is catalyzed to water by Gpxl or catalase (4). Consequently, it is the concerted action of all the antioxidant enzymes that enables the cell to function in an otherwise noxious environment.

The birth of a fetus results in a transition from an hypoxic environment in utero $\left[\mathrm{PO}_{2} 2.66-3.99 \mathrm{kPa}(20-30 \mathrm{~mm} \mathrm{Hg})\right]$ to a relatively hyperoxic environment $[13.3 \mathrm{kPa}(100 \mathrm{~mm} \mathrm{Hg})](5)$. Thus, the birth of a fetus involves a significant oxidative stress that can result in the generation of toxic reactive oxygen species (5). Indeed. numerous studies have demonstrated a surge in the activity of pulmonary antioxidant enzymes in the fetus during late gestational stages $(5-10)$. The reasons for such an increase have been proposed to be the preparation of the pulmonary system for the acute change in oxygen concentration that occurs at birth. However, this increase in the activity of the antioxidant enzymes in late gestation may be the result of other factors. Such a possibility has been suggested by Rickett and Kelly (5), who have shown that a rise in the activity of antioxidant enzymes also occurs in the livers of guinea pig fetuses during late gestation. No data are currently available on the expression of antioxidant enzymes in other organs of late-gestational mammalian fetuses. To gain further insight into the significance of the rise in antioxidant enzyme activity in organs of late-gestational fetuses and neonates and to examine how widespread this phenomenon is, we investigated the expression of the Sod 1 and Gpxl genes in a variety of murine embryonic, fetal, and neonatal organs. Specifically, this study investigated whether a change in mRNA levels for these two genes was related to a developmental change in oxidant stress.

\section{MATERIALS AND METHODS}

Animals. Female mice were mated overnight and checked the next day for the presence of vaginal plugs (11). This day was designated $\mathrm{d} l$ of gestation. Pregnant mice were killed by cervical dislocation on specified days. Neonatal mice were killed on $\mathrm{d} 1$ and 7 after birth, respectively. Between 8 to 25 whole embryos and individual organs were pooled for each specific time point. 
Each of the organs and tissues was carefully dissected from the mice, ensuring that no contamination from other organs or tissue resulted. Furthermore, individual organs were rinsed in PBS, $\mathrm{pH}$ 7.0 , several times. These organs were immediately frozen in liquid nitrogen for RNA analysis. These experiments were approved by the Animal Ethics Committee of Monash University.

$R N A$ extraction. Total cellular RNA was extracted according to the method of Chomczynski and Sacchi (12). Twenty- $\mu \mathrm{g}$ aliquots of RNA were lyophilized for Northern analysis, and 20-, $10-, 5-$, and 2.5- $\mu \mathrm{g}$ aliquots were used for dot-blot analysis.

Cloning and sequencing of murine Sodl cDN.A. Total cellular RNA from 1-d neonatal murine brains was used for cDNA synthesis in the following reaction: $10 \mu \mathrm{g}$ of RNA were mixed with $20 \mathrm{pM}$ of an oligo $\mathrm{dT}_{(15)}$ adaptor containing a $N o t \mathrm{I}$ restriction site (shown in bold) $\left(5^{\prime}\right.$-[T] ${ }_{15}$ CGCCGGCGCTTAAGGGCCC $-3^{\prime}$ ). The RNA plus added oligonucleotide was heated to $65^{\circ} \mathrm{C}$ and thereafter slowly cooled to $42^{\circ} \mathrm{C}$. For the cDNA reaction the following were added and incubated at $42^{\circ} \mathrm{C}$ for $1 \mathrm{~h}: 1.0$ $\mathrm{mM}$ deoxyribonucleoside triphosphate. $50 \mathrm{mM}$ Tris- $\mathrm{HCl}(\mathrm{pH}$ 8.3), $6 \mathrm{mM} \mathrm{MgCl}_{2}, 10 \mathrm{mM}$ DTT, $35 \mathrm{IU}$ RNasin, and $20 \mathrm{IU}$ Moloney murine leukemia virus reverse transcriptase. An oligonucleotide (5'-CTTCTCGTCTAGATCTCTCTG-3') homologous to the most $5^{\prime}$ sequence of a murine Sod 1 cDNA (13) was synthesized. Two base changes (underlined) were made to create an additional $\mathrm{XbaI}$ cloning site (shown in bold). This oligonucleotide, together with the oligo $\mathrm{dT}_{(15)}$ adaptor described above, was used in the polymerase chain reaction to amplify a murine Sod 1 cDNA from the neonatal brain cDNA library generated above. The polymerase chain reaction was performed as follows: $20 \mathrm{pM}$ of each oligonucleotide was added to $0.5 \mu \mathrm{g}$ cDNA in $10 \mathrm{mM}$ Tris- $\mathrm{HCl}(\mathrm{pH} 8.3), 1.25 \mathrm{mM}$ deoxyribonucleoside triphosphate, $0.1 \%$ Triton-X100,1.5 mM MgCl , and $5 \mathrm{IU}$ Taq polymerase (Promega, Madison, WI): 35 cycles of $1 \mathrm{~min}$ at $95^{\circ} \mathrm{C}, 1 \mathrm{~min}$ at $65^{\circ} \mathrm{C}$, and $2 \mathrm{~min}$ at $72^{\circ} \mathrm{C}$. The 600 -bp polymerase chain reaction product was excised and purified using Geneclean (Bio-101. CA). The purified DNA was restricted with $N o t I$ and $X b a I$ and cloned into $\mathrm{pGEM}-9 \mathrm{Zf}(-)$. The nucleotide sequence was determined by the dideoxynucleoside chain-termination method (14) using universal forward and reverse primers to sequence from both ends of the insert. The chemical reaction products were electrophoresed on urea/polyacrylamide $(30: 1)$ gels. Sequence data were analyzed using PC/Gene Software (IntelliGenetics, Inc., Mountain View, CA).

Northern and dot-blot analysis. The techniques used for gel electrophoresis, Northern transfer, and dot-blot analysis have been previously described (11). The murine Sod 1 probe $(613 \mathrm{bp})$ was released from pGEM-9Zf(-) after restriction with $\mathrm{XbaI}$ and Not I. Human catalase (plasmid pCAT 10) was obtained from the American Type Culture Collection (Rockville, MD). Murine $\beta$ actin and murine Gpxl were gifts from Drs. T. Papas and I. Chambers, respectively. An oligonucleotide homologous to an $18 \mathrm{~S}$ ribosomal rat sequence (5'-CGGCATGTATTAGCTCTAGAATTACCACAG-3') was synthesized. Hybridization probes were prepared and labeled as previously described (11). The 18S oligonucleotide was end-labeled using polynucleotide kinase (Promega) and ['32P]ATP (Amersham, Buckinghamshire, UK). Northern filters were prehybridized, and they were hybridized with Sod 1. Gpx 1 , and $\beta$-actin probes as previously described (11). The $18 \mathrm{~S}$ ribosomal oligonucleotide probe was hybridized in molar excess. These filters were washed in $0.1 \times$ sodium chloride, sodium phosphate. EDTA at $65^{\circ} \mathrm{C}$ for $15 \mathrm{~min}$. Prehybridization conditions and hybridization with an $18 \mathrm{~S}$ oligonucleotide were as follows: prehybridization was for $2-4 \mathrm{~h}$ in $50 \%$ formamide, $2.5 \times$ sodium chloride, sodium citrate, $5 \times$ Denhardt's solution, $25 \mathrm{mM} \mathrm{H} \mathrm{PO}_{4}$ ( $\mathrm{pH} 7.4$ ), $0.05 \mathrm{mg} / \mathrm{mL}$ salmon sperm DNA, and $0.05 \%$ SDS, and hybridization occurred for $14-16 \mathrm{~h}$ at $37^{\circ} \mathrm{C}$ in the same solution. These filters were washed in $1 \times$ sodium chloride, sodium phosphate. EDTA, $0.1 \%$ SDS at $40^{\circ} \mathrm{C}$ for $15 \mathrm{~min}$. Autoradiography was performed using intensifying screens at $-70^{\circ} \mathrm{C}$ and Fuji $\mathrm{x}$-ray $\mathrm{RX}$ medical film.
Northern blots were first hybridized with Sodl, the probe removed (11), and then sequentially hybridized with the Gpx 1 probe, the $\beta$-actin probe, and the $18 \mathrm{~S}$ oligonucleotide. Before rehybridization of filters, autoradiography was carried out to confirm that no residual signal remained. The transcript size(s) for each of the genes was confirmed on Northern blots relative to $28 \mathrm{~S}$ and $18 \mathrm{~S}$ RNA and was also approximated by the use of size markers as previously described (11). Northern-blot and dotblot autoradiograms were scanned (for quantitation) using an Ultroscan XL LKB densitometer (Bromma. Sweden). Laser densitometry for all of the autoradiograms were conducted on lighter exposures of the filters where the signal density or radioactivity was still in the linear range. Care was also taken to pass the scanning beam in a path where nonspecific signals were not present and thus did not interfere with the quantitation. Sod l and Gpxl expression was corrected for RNA loading and is shown relative to $\beta$-actin and $18 \mathrm{~S}$ ribosomal RNA. The mRNA levels of each gene are expressed as a ratio of the area under the curve for the signal of that particular gene over the area under the curve for $\beta$-actin, and this ratio was corrected relative to $18 \mathrm{~S}$ ribosomal RNA to correct for slight differences in RNA loading between different lanes. All the data in this study were similar when corrected relative to $\beta$-actin as compared with that corrected relative to $\beta$-actin and subsequently to $18 \mathrm{~S}$ ribosomal RNA. It is also important to note that rehybridization of the filters with another housekeeping gene (GAPDH) showed that the levels of $\beta$-actin and GAPDH followed one another extremely closely, and both were significantly different from that of $18 \mathrm{~S}$ ribosomal RNA (data not shown). One lane on each filter was loaded with 15-d embryo total RNA-this served as a control and facilitated comparison across different filters by normalization of each filter relative to this sample when required.

Tissue preparation and enzymatic assay's. Approximately 10 organs were pooled for each time point. Tissues were homogenized $(0.5 \mathrm{~g} / \mathrm{mL}$ wet $w \mathrm{t})$ in $65 \mathrm{mM}$ phosphate buffer containing $1 \%$ Triton-X 100 and centrifuged at $105000 \times g$ for $1 \mathrm{~h}$. The supernatant was used to measure both Sod 1 and Gpxl activity.

Sod activity was assayed according to Elroy-Stein et al. (15). To measure total Sod activity, we added $250 \mu \mathrm{L}$ of supernatant to $25 \mu \mathrm{L}$ of xanthine $(1.142 \mathrm{mg} / \mathrm{mL}), 25 \mu \mathrm{L}$ of hydroxylammonium chloride, $125 \mu \mathrm{L}$ of $\mathrm{H}_{2} \mathrm{O}$, and $75 \mu \mathrm{L}$ of xanthine oxidase $(0.1 \mathrm{IU} / \mathrm{mL})$. The mixture was incubated at $25^{\circ} \mathrm{C}$ for $20 \mathrm{~min}$. Thereafter, $0.5 \mathrm{~mL}$ of sulfonilic acid $(3.3 \mathrm{mg} / \mathrm{mL})$ and $0.5 \mathrm{~mL}$ of $\alpha$-naphthylamine ( $1 \mathrm{ng} / \mathrm{mL}$ ) were added and further incubated at room temperature for $20 \mathrm{~min}$. The absorbance was measured at $530 \mathrm{~nm}$. The addition of $125 \mu \mathrm{L}$ of $\mathrm{KCN}(4 \mathrm{mM})$ in place of $\mathrm{H}_{2} \mathrm{O}$ in the above reaction specifically inhibits Sodl activity. Thus subtraction of the Sod activity remaining after KCN treatment (i.e. Sod2) from the total Sod activity gives the Sod I activity of the sample. Sod l activity is expressed as $\mathrm{IU} / \mathrm{mg}$ tissue.

Gpx 1 activity was assayed according to the method of Lawrence and Burk (16). Briefly, $800 \mu \mathrm{L}$ of the following solution was prepared for each sample and incubated at room temperature for $5 \mathrm{~min}$ : $62.5 \mathrm{mM}$ potassium phosphate buffer $(\mathrm{pH} 7.0) .1 \mathrm{mM}$ EDTA. $1 \mathrm{mM} \mathrm{NaN}, 0.2 \mathrm{mM} \beta$-NADPH. 1 IU glutathione reductase, and $0.31 \mathrm{mM}$ reduced glutathione. Thereafter, $0.1 \mathrm{~mL}$ of $0.25 \mathrm{mM} \mathrm{H}_{2} \mathrm{O}_{2}$ was added and further incubated at room temperature for $5 \mathrm{~min}$, and the reaction was commenced by the addition of $0.1 \mathrm{~mL}$ of supernatant. The change in absorbance was measured at $340 \mathrm{~nm}$ for $5 \mathrm{~min}$. Gpx 1 activity is expressed as $\mu \mathrm{mol} \mathrm{NADPH}$ oxidized $/ \mathrm{min} / \mathrm{mg}$ tissue.

\section{RESULTS}

Cloning and Sequencing of Murine 'DNA for Sodl. The Sod 1 cDNA clone isolated contains 53 bp $5^{\prime}$ from the ATG start site, 462 bp coding sequence and 75 bp $3^{\prime}$ of the stop codon. A coding region of $462 \mathrm{bp}$ is consistent with other published sequences for murine Sodl cDNA $(13,17)$. Our sequence is identical to that of Bewley (17), including the atypical polyade- 
nylation sequence (ATTAAA), with the exception that they have an additional $A$ inserted at position 486 and that we find a $T$ instead of an $A$ at position 499. Our cDNA clone is identical to that of Getzoff et al. (13) with regard to these two differences. However, we have one difference in our sequence compared with Getzoff et al. (13), namely, we do not find a G inserted between position 470 and 471 . In this instance our sequence is the same as that of Bewley (17). These differences in our sequence from that of Bewley (17) and Getzoff et al. (13) do not affect the amino acid sequence of the clone because they occur in the $3^{\prime}$ untranslated region. Northern analysis of murine tissue showed that our cDNA probe detected one transcript of approximately $0.7 \mathrm{~kb}$ as expected (18).

Developmental Expression of Sodl and Gpxl in Organs and Amnion of Mouse Fetuses. Lung. Sodl and Gpxl expression increases sharply before or around the time of birth (Figs. I and $2 a$ ). This increase is manifested by the 5 - and 7 -fold higher levels of Sodl and Gpxl mRNA, respectively, in the lungs of 1-d neonatal mice as compared with those of 19-d fetal mice. Thereafter, in 7-d neonatal mice, a decline in the mRNA levels for Sod 1 and Gpxl occur. The profiles of Sod 1 and Gpx 1 mRNA are similar in late gestation and neonatal development. These profiles for Sod 1 and Gpx $1 \mathrm{mRNA}$ were similar irrespective of whether the Sod 1 and Gpx 1 mRNA levels were expressed relative to $\beta$-actin or $\beta$-actin and $18 \mathrm{~S}$ ribosomal RNA or $18 \mathrm{~S}$ ribosomal RNA only (data not shown). However, in the liver the data is significantly different when expressed relative to $\beta$-actin (or GAPDH) or $18 \mathrm{~S}$ ribosomal RNA (see below).

The mRNA levels for Sod 1 and Gpxl were also examined at time periods earlier than d 17 (viz. d 14 to 16). Curiously, the Sod 1 mRNA levels were relatively high in these earlier periods (Fig. 3). Indeed, the Sod $1 \mathrm{mRNA}$ levels in 15-d lungs were higher than at any other time in the gestational and neonatal periods. Gpx 1 mRNA levels were also higher in 15-d and 16-d lungs than at any other stage in development.

Liver. Sod 1 and Gpxl expression relative to $\beta$-actin increases from d 17 through d 19 (approximately 20 - and 3-fold increase, respectively) (Figs. 1 and 2 b). Thereafter, Sod 1 and Gpx 1 mRNA levels show a marked decline at or around the time of birth. This decline is still evident on $\mathrm{d} 7$ of neonatal life. The profiles of
Sod 1 and Gpxl mRNA levels in the livers of mice at various stages of development are also similar.

With regard to the expression of Sod 1 and Gpxl relative to $18 \mathrm{~S}$ ribosomal RNA, if the data are analyzed in this manner, a different pattern of expression is obtained from that described in the preceding paragraph. The levels of Sod 1 and Gpx I mRNA are greatly elevated between $d 19$ of gestation and the first $d$ of neonatal life (Fig. 4). Gpx I mRNA levels start off at very high on $\mathrm{d} 17$, are reduced some 6 -fold on $\mathrm{d} 18$ and $\mathrm{d} 19$, and thereafter surge at or around the time of birth. On the first day of neonatal life Gpx 1 mRNA levels are approximately 6.5-fold higher than that of 19-d fetal livers. Sod 1 mRNA levels also show low levels of expression on d 17 to 19 of gestation and then an approximately 4 -fold elevation between $\mathrm{d} 19$ and the first $\mathrm{d}$ of neonatal life.

With regard to Sod 1 and Gpx 1 activity, this experiment was undertaken for two reasons: 1 ) to investigate the correlation of mRNA levels for Sodl and Gpxl with enzyme activity: and thereby 2) to determine which of the two methods of mRNA analysis above was more accurate. especially because the liver was the only organ investigated that showed a difference in Sod 1 and Gpx I mRNA profiles. This was dependent on whether the data was corrected relative to $18 \mathrm{~S}$ ribosomal RNA only or relative to a housekeeping gene ( $\beta$-actin or GAPDH) and $18 \mathrm{~S}$ ribosomal RNA (or to a housekeeping gene only because no differences in the patterns for $\beta$-actin/GAPDH or $18 \mathrm{~S}$ ribosomal RNA were obtained).

The enzyme activity for Sod 1 and Gpx 1 was similar (Fig. 5a) to the mRNA profiles for these two enzymes as demonstrated in the earlier discussion regarding expression relative to $\beta$-actin [i.e. the data corrected relative to $\beta$-actin and $18 \mathrm{~S}$ ribosomal RNA (Fig. $2 b)$ ] (or either $\beta$-actin or GAPDH alone, data not shown). These data demonstrate that the activity of Sod 1 and Gpx 1 are elevated in late gestation at or around the time of birth. Furthermore, the mRNA profile for Sod 1 and Gpx 1 correlate well with the activity for these two enzymes in the time periods investigated.

Brain. With regard to mRNA profiles, an increase in Sod 1 mRNA, and not Gpxl mRNA, occurs in the brain of lategestation and neonatal mouse fetuses (Figs. 6 and 2c). An approximately 3 -fold increase in Sod 1 mRNA levels occurs between
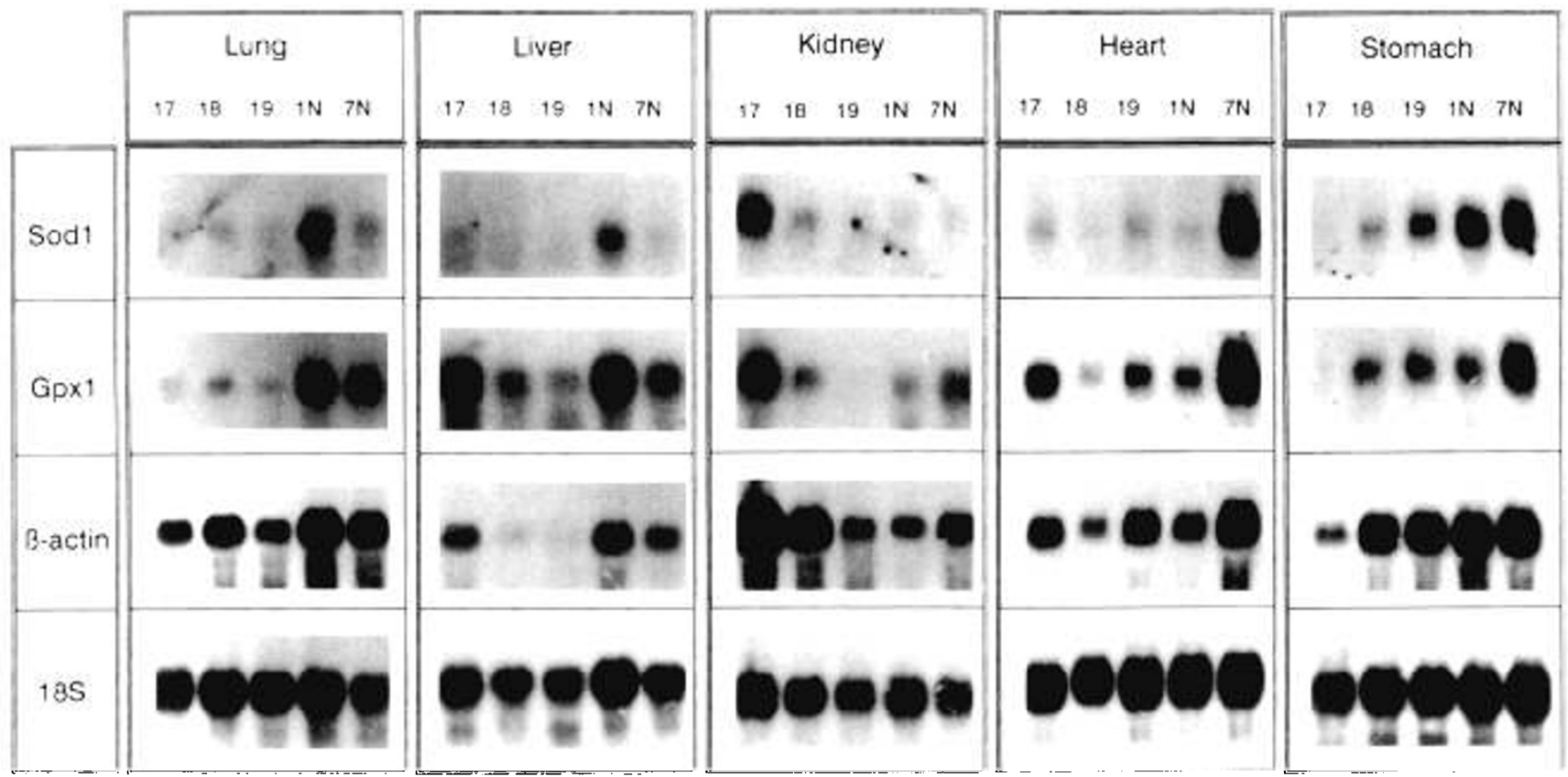

Fig. 1. Northern-blot analysis of total RNA from organs of 17-d mouse fetuses through to 7-d neonates. Filters were hybridized with a probe for Sodl, stripped, and sequentially rehybridized with Gpxl, $\beta$-actin, and $18 \mathrm{~S}$ ribosomal RNA probes. Numbers represent the following: 17 . 17 th $\mathrm{d}$ of gestation; 18,18 th $\mathrm{d}$ of gestation; 19,19 th $\mathrm{d}$ of gestation: $I N, 1$-d neonatal mice: $7 N, 7$-d neonatal mice. 

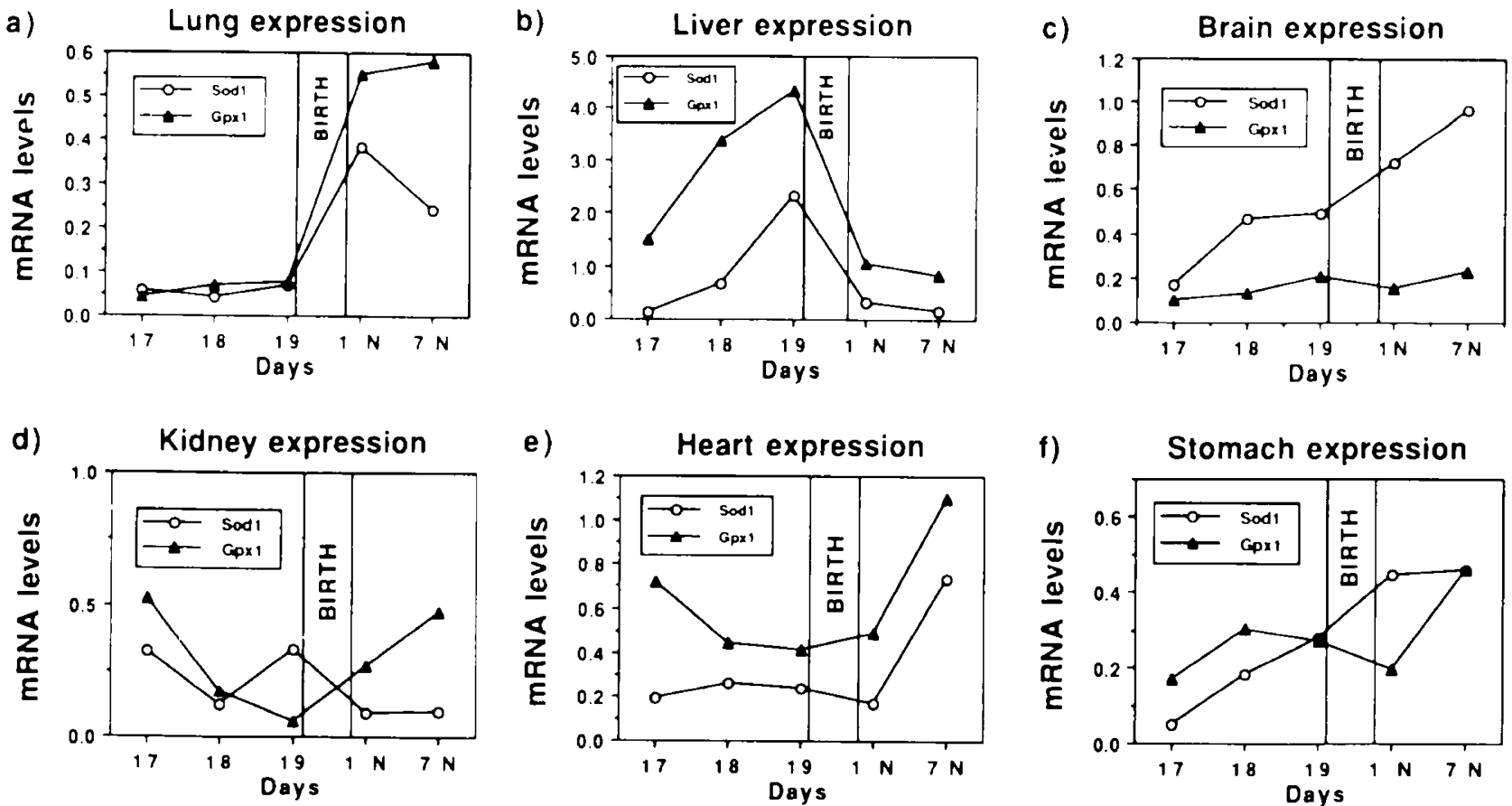

Fig. 2. Graphic representation of the quantitative expression of Sodl and Gpxl (relative to $\beta$-actin and $18 \mathrm{~S}$ ribosomal RNA) in the various organs of $17-d$ mouse fetuses through to $7-d$ neonates. The organs analyzed were the lung. liver, brain, kidney, heart, and stomach. The Northern and dot blots shown in Figures 1 and 6 were scanned with a laser densitometer, corrected for RNA loading, and shown relative to 3 -actin and $18 \mathrm{~S}$ ribosomal RNA. Note: These profiles are similar if the data are corrected relative to $\beta$-actin only [or GAPDH (data not shown)] and $18 \mathrm{~S}$ ribosomal RNA only [except the liver (see text)].

\section{Lung developmental expression}

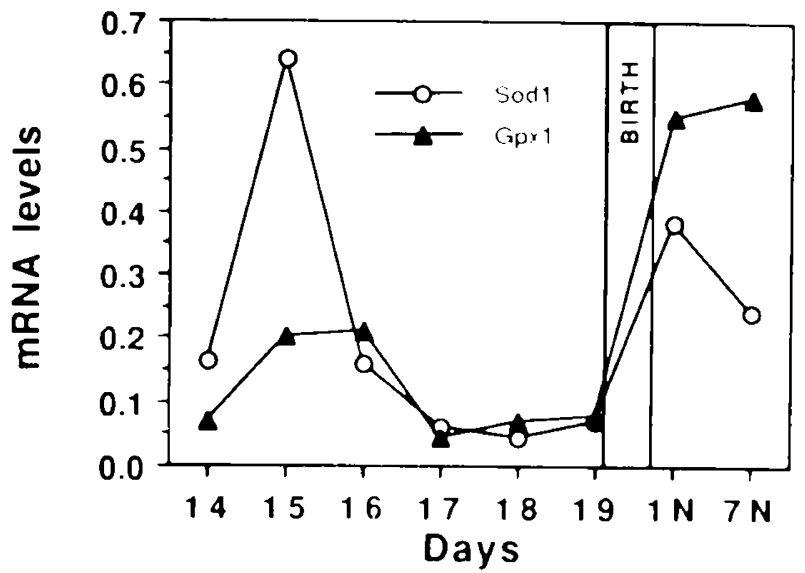

Fig. 3. Sodl and Gpxl mRNA levels in lungs of mice between d 14 to 19 of gestation and $1-d$ and $7-d$ neonates. The mRNA levels are shown relative to $\beta$-actin and $18 \mathrm{~S}$ ribosomal RNA. Northern blots shown in Figure 1 (d 17 onward) and data not shown for $d 14$ to 16 were densitometrically scanned and corrected for $\beta$-actin and $18 \mathrm{~S}$ ribosomal RNA.

d 17 and d 19 of gestation. Sod 1 mRNA levels continue to rise into the neonatal stages of development (a further 2-fold increase occurs). Gpx I mRNA levels, on the other hand, do not demonstrate a similar increase (if at all) in mRNA levels in late gestation. These levels remain relatively unchanged during late development and after birth.

The activity of Sod 1 and Gpxl (Fig. $5 b$ ) correlated well with the mRNA profiles of the two genes (Fig. 2 $c^{\prime}$ ). Sod 1 activity was higher on $d 19$ of gestation as compared with earlier periods of development, and the Sod 1 activity was even higher in 7-d neonatal brains. Gpxl activity, like that of the mRNA levels,

\section{Liver corrected relative to} $18 \mathrm{~S}$ only

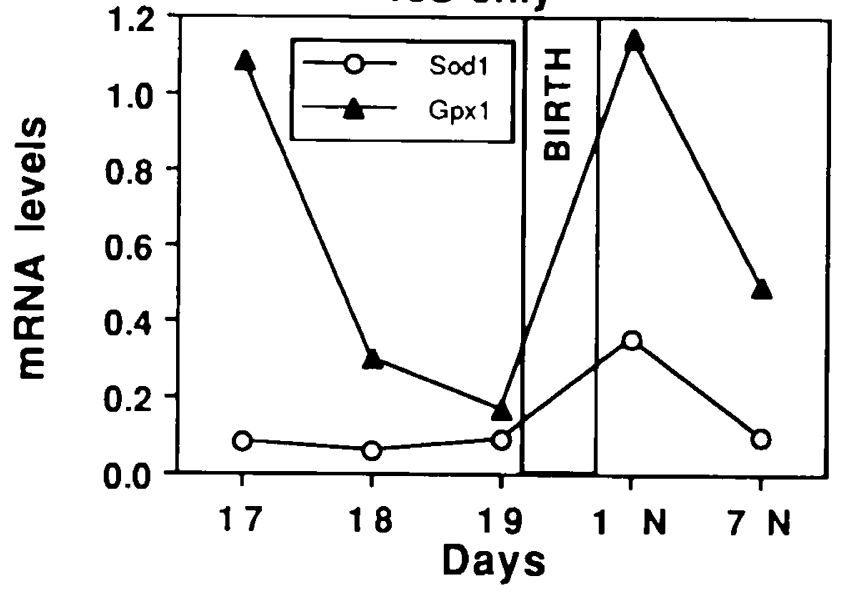

Fig. 4. The Sod 1 and Gpx 1 mRNA profile of the liver when the data in Figure 1 is corrected relative to $18 \mathrm{~S}$ ribosomal RNA. Note: The liver is the only organ that showed a difference in Sodl and Gpxl mRNA profiles when the data were corrected relative to $\beta$-actin (or GAPDH) and 18 S ribosomal RNA as compared with that relative to $18 \mathrm{~S}$ only.

was relatively unchanged in late development and after birth. These data, together with those for the liver, provide further evidence for a good correlation between mRNA profiles and enzyme activity. Consequently, mRNA levels only were subsequently studied.

Kidney: Gpx 1 mRNA levels, and not Sod1, increase in mouse kidneys before or around the time of birth (Figs. 1 and $2 d$ ). The mRNA levels for Sod 1 and Gpxl are high in 17-d fetal kidneys. Thereafter, the levels of Sod 1 and Gpx 1 mRNA show a decline in 18-d fetal kidneys. The Sod 1 mRNA levels demonstrate a slight elevation on $d 19$ as compared with $d 18$. In 1 - and 7-d 
a)

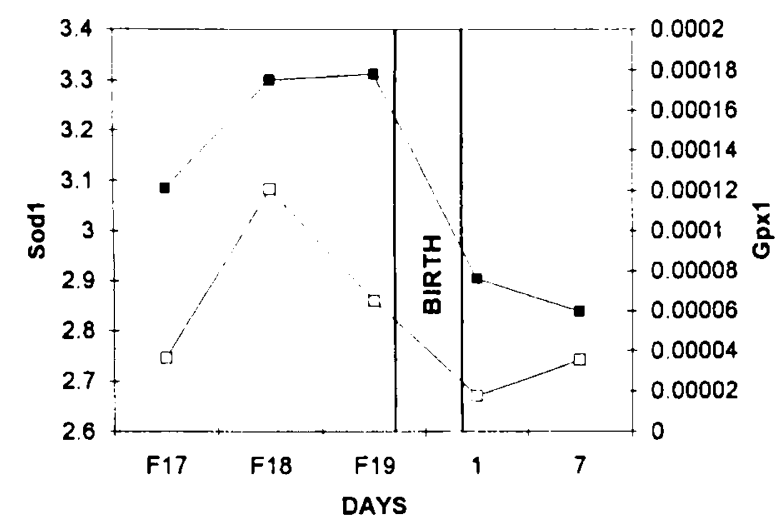

b)
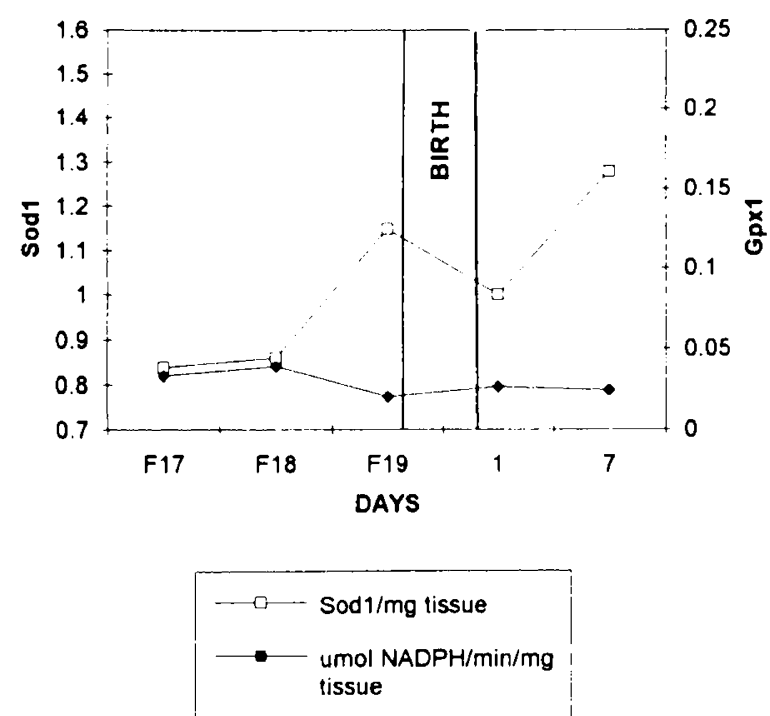

Fig. 5. Sod 1 and Gpx 1 activity in the liver $(a)$ and brain $(b)$ of 17-d to 19-d mouse fetuses and 1-d and 7-d neonatal mice. The Sodl activity is expressed as IU/mg tissue and the Gpxl activity as $\mu \mathrm{mol}$ NADPH/ $\mathrm{min} / \mathrm{mg}$ tissue.

neonatal mice the Sod 1 mRNA levels are similar to $d 18$ levels. Gpx 1 mRNA levels, on the other hand, decline on d 19 of gestation as compared with that of $d 18$. Thereafter, the levels of Gpx 1 mRNA show an increase, which persists into neonatal development.

Heart. Sod 1 and Gpx 1 mRNA levels fail to demonstrate a late fetal surge in the heart (Figs. 1 and $2 e$ ). Sod 1 mRNA levels are essentially unchanged throughout this period and into the first day of neonatal development. However, a sharp rise (a 4-fold increase) in Sodl mRNA levels occurs in the heart of 7-d neonatal mice as compared with that of 1-d neonatal mice. Gpx 1, on the other hand, is expressed at high levels in 17-d fetuses, and these levels decline on d 18 and 19. Thereafter, Gpxl demonstrates a modest (1.2-fold) increase in mRNA levels just before or at birth. A further 2-fold increase in Gpx 1 mRNA levels occurs in 7-d neonatal mice as compared with 1-d neonatal mice.

Stomach. Sod 1 mRNA levels, and not those of Gpx 1, show an elevation at or around the time of birth. A steady increase in Sod 1 expression occurs before (approximately 6-fold increase) and after birth (a further 1.6-fold increase) (Figs. 1 and $2 f$ ). A 2fold rise in Gpxl expression occurs on d 18 of gestation as compared with d 17. Thereafter, Gpx 1 mRNA levels are similar

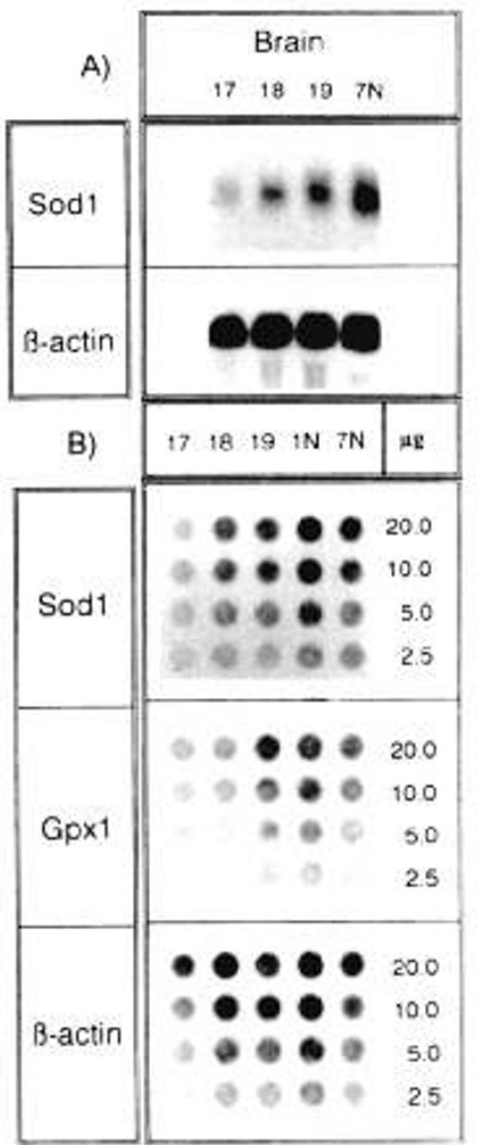

Fig. 6. Northern-and dot-blot analysis of total RNA from the brains of 17-d fetuses through to 7-d neonates. Northern blots $(A)$ were first hybridized with Sod 1 , stripped, and rehybridized with $\beta$-actin. The filters degenerated after the $\beta$-actin hybridizations, and hence the analysis was also conducted on dot blots. Dot blots $(B)$ were hybridized with Sodl, stripped, and rehybridized sequentially with Gpxl and $\beta$-actin.

until d 1 of neonatal development. However, an approximately 2.5-fold increase in Gpx 1 mRNA occurs in 7-d neonatal stomachs as compared with those of $1-d$ neonates.

Amnion. The Northern blots in Figure $7 a$ show the expression of Sod 1 and Gpxl in the amnion of different aged conceptuses. Sod 1 expression progressively increases in the amnion of $\mathrm{d} 10$ (the earliest stage investigated) to $\mathrm{d} 14$ conceptuses (Fig. $7 \mathrm{~b}$ ). The increase over this period is approximately 5 -fold. The levels of Sod 1 mRNA decline after d 14 of embryogenesis, as evidenced by the 3-fold lower levels of Sod 1 mRNA in 16-d amnions. Gpx 1 expression remains relatively constant in the amnion on $\mathrm{d} 10$ and d 11 of gestation. On d 12, however, an approximately 3fold increase occurs in Gpx 1 mRNA levels. The levels of Gpx 1 mRNA decline in 13-d amnions and are still lower in 14-d and 16-d amnions as compared with those of 13-d conceptuses.

Comparison of Sodl and Gpxl Expression in Organs of Different Aged Fetuses. Having compared the expression of Sodl and Gpxl mRNA levels in individual organs of fetuses on different days of late-gestational development, we compared the expression of Sod 1 and Gpxl in the different organs of fetal, neonatal, and adult mice at specific stages of development. These investigations were conducted with a view of gaining further insight into the reasons for the modulations of Sodl and Gpxl mRNA levels.

Day 14 fetuses. The liver expresses the highest levels of both Sod 1 and Gpx 1 in 14-d murine fetuses (Figs. 8 and $9 a$ ). The descending order for Sodl expression is as follows: liver $>$ heart $>$ kidney $>$ brain $>$ intestine $>$ stomach $>$ lung. The order for Gpxl expression is as follows: liver $>$ kidney $>$ heart $>$ lung $>$ brain $>$ intestine $>$ stomach. 


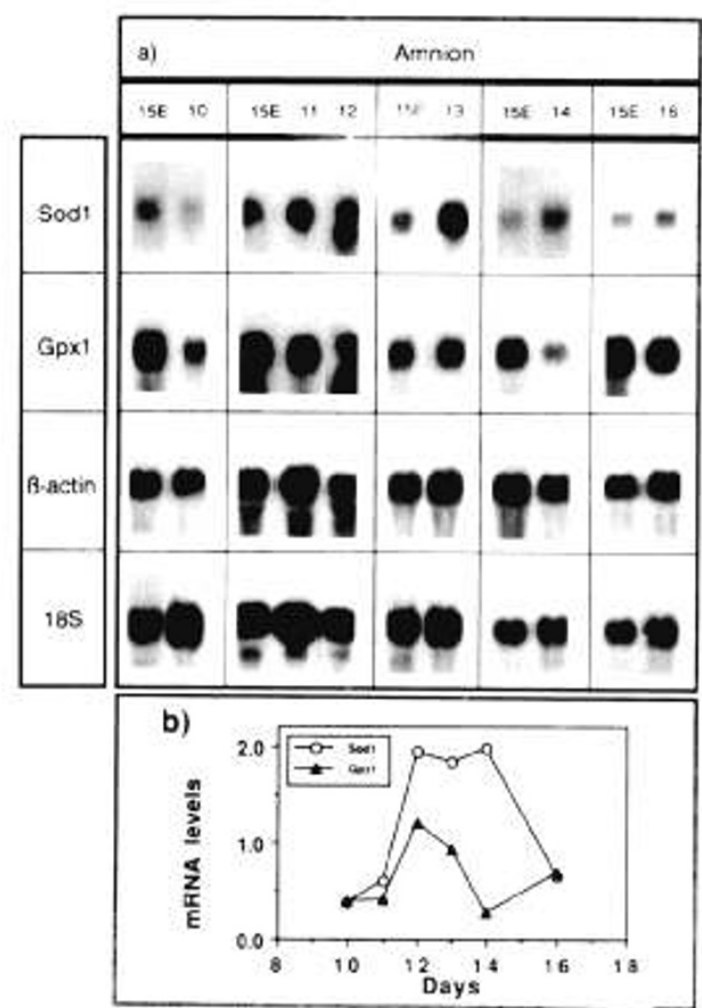

Fig. 7. The expression of Sod I, Gpx 1, and $\beta$-actin in the amnions of 10-d, 11-d, 12-d, 13-d, 14-d, and 16-d conceptuses. Northern-blot filters (a) of total RNA from the amnions were hybridized with the Sod 1 probe. stripped, and sequentially hybridized with Gpx $1, \beta$-actin, and $18 \mathrm{~S}$ ribosomal probes. Each filter contained a track loaded with total RNA from a 15-d embryo ( $15 E)$, which served as an internal control and facilitated comparison across filters. Graphic representation $(h)$ of the quantitative expression of Sod 1 and Gpxl (relative to $\beta$-actin and $18 \mathrm{~S}$ ribosomal RNA) in the amnions shown in $a$. The Northern blots shown in $a$ were scanned with a laser densitometer, corrected for RNA loading, and shown relative to $\beta$-actin and $18 \mathrm{~S}$ ribosomal RNA.

Day 16 fetuses. The liver is still the organ expressing the highest levels of Sod 1 mRNA in 16-d murine fetuses (Figs. 8 and $9 b$ ). The order of Sod 1 expression in organs of 16-d murine fetuses is as follows: liver $>$ intestine $>$ heart $>$ kidney $>$ lung $>$ stomach $>$ brain. The order of Gpx 1 mRNA levels in these fetuses is as follows: heart $>$ liver $>$ lung $>$ kidney $>$ intestine $>$ brain $>$ stomach.

Day 1 neonates. The liver is also the organ with the highest
mRNA levels for Sod 1 immediately after birth (Figs. 8 and $9 c^{\prime}$ ). Sod $1 \mathrm{mRNA}$ levels in the liver are approximately 1.5-fold greater than the kidney, which expressed the second highest amount of Sod 1. The level of Sod 1 in the heart is similar to that in the kidney. The heart is followed by (in descending order of expression) stomach, lung, brain, and intestine. The $\mathrm{d} 1$ neonatal liver also has the greatest amount of Gpx 1 mRNA. This amount is approximately 2 -fold greater than the heart, which is followed by the kidney, lung, stomach, intestine, and brain.

Day 7 neonates. The quantitative pattern of Sod 1 and Gpxl expression changes in the organs of 7-d neonatal mice (Figs. 8 and $9 d$ ). At this stage of development, the organ with the highest mRNA levels for Sod 1 is the heart. followed by thymus $>$ brain $>$ liver $>$ lung $>$ stomach $>$ spleen $>$ kidney. The organ with the highest mRNA for Gpxl is the spleen. The levels of Gpxl mRNA in the spleen are approximately 3 -fold higher than those of the liver (the organ with the second highest level of Gpx 1 mRNA). The liver is followed by the heart $>$ thymus $>$ lung $>$ stomach $>$ brain $>$ kidney.

Adult organs. At this stage of development, the liver is the organ with the highest levels of Sod 1 mRNA among the seven adult organs studied (Figs. 8 and $9 e$ ). This level is approximately 2 -fold higher than that of the spleen, which is the organ with the second highest levels of Sod 1 mRNA. The other organs have relatively similar levels of Sod $1 \mathrm{mRNA}$ with the order as follows: lung $>$ kidney $>$ brain $>$ heart $>$ ovary. The adult spleen is the organ with the highest levels of Gpxl mRNA. This level is approximately 7.5-fold greater than the level of Gpx 1 mRNA seen in the liver (the organ with the second highest level of Gpx 1 mRNA). The remaining organs follow as listed: kidney (with approximately a 4-fold greater Gpx 1 expression) $>$ lung $>$ heart $>$ ovary $>$ brain. The levels of mRNA for Sod $l$ and Gpxl are generally higher in adult organs than in neonatal and embryonic organs, with Gpxl levels in the brain being the exception.

\section{DISCUSSION}

We have shown the following in this study: 1) Sod I and Gpx 1 mRNA levels are quantitatively regulated in a temporal and tissue-specific manner during later fetal development, 2) a surge in expression of both Sod 1 and Gpx 1 mRNA levels occurs just before or at birth in the lung and stomach and in late gestation in the liver (both mRNA levels and enzyme activity); 3) an elevation in Sod 1 occurs before or at birth in the brain: 4) the kidney shows an elevation in Gpxl mRNA levels at or around the time of birth: 5) the heart does not demonstrate a surge at birth in the expression of the antioxidant enzymes studied: 6) the expression of Sod 1 and Gpx 1 mRNA progressively increases in the amnion until d 14 and $d 13$ of gestation, respectively, after

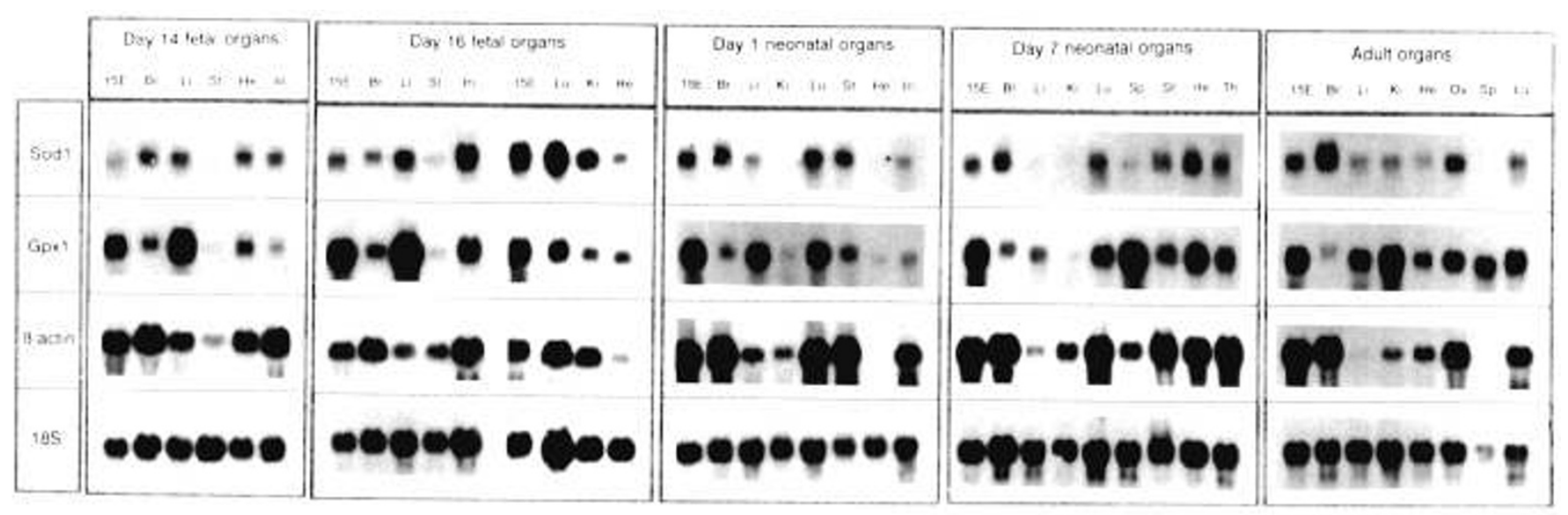

Fig. 8. Northern-blot filters of total RNA from organs of 14-d and 16-d mouse fetuses, 1-d and 7-d neonatal mice, and adult mice. Filters were hybridized with a probe for Sod1, stripped, and sequentially rehybridized with Gpx1, $\beta$-actin. and $18 \mathrm{~S}$ ribosomal RNA probes. $15 E$. 15-d embryo: $B r$, brain; $L i$, liver, $S t$, stomach; $H e$, heart: $I n$. intestine: $L u$. lung: $K i$, kidney: $T h$, thymus: $S p$, spleen; $O r$, ovary. 

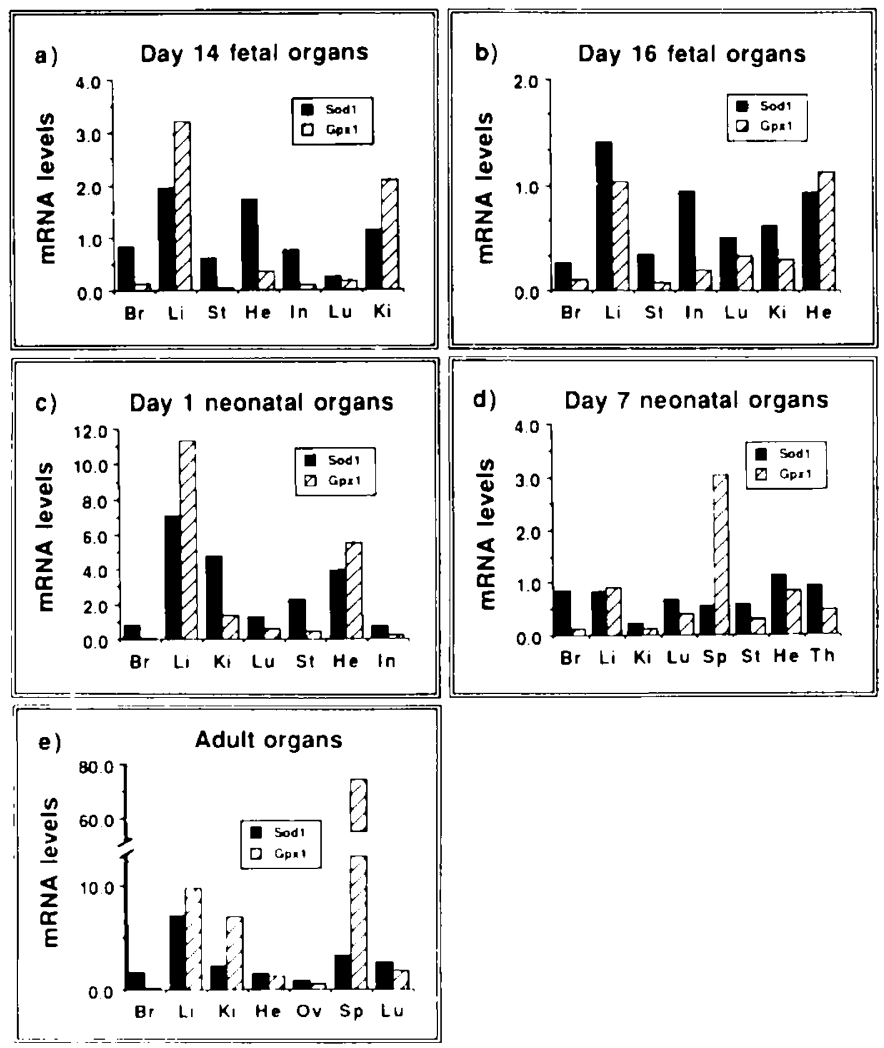

Fig. 9. Graphic representation of the quantitative expression of Sod1 and Gpxl (relative to $\beta$-actin and $18 \mathrm{~S}$ ribosomal RNA) in the various organs of 14-d $(a)$ and 16-d $(b)$ mouse fetuses, 1-d (c) and 7-d $(d)$ neonatal mice, and adult $(e)$ mice. The Northern blots shown in Figure 8 were scanned with a laser densitometer. corrected for RNA loading. and shown relative to $\beta$-actin and $18 \mathrm{~S}$ ribosomal RNA. The data for the liver and kidney of 14-d fetuses are shown even though they are not shown in Figure 8.

which a decline occurs in expression of these genes; 7) of the organs studied, the liver is the one with the highest levels of both Sod 1 and Gpx 1 mRNA levels during murine embryogenesis and immediately after birth; it is also the organ with the highest expression of Sod 1 mRNA in the adult; and 8 ) the spleen is the organ with the highest levels of Gpxl mRNA in 7-d neonatal and adult mice. These findings are relevant to an analysis of the reason for the surge in antioxidant enzymes in late gestation or at birth, and to the levels of antioxidant gene product in different organs of embryonic, neonatal, and adult mice.

Previous studies have mainly focused on the activity of antioxidant enzymes in the lung in late gestation or at birth. These studies $(5-9,19)$ have demonstrated that in a variety of animal species (guinea pig, rabbit, hamster, and rat) a surge in pulmonary antioxidant enzyme activity occurs in late gestation before birth These findings have been ascribed to the preparation of the pulmonary antioxidant system, in a manner analogous to the surfactant system (5), for the process of birth. During the birth process the fetus will move from a relatively hypoxic environment to an hyperoxic environment where an approximately 5fold elevation in oxygen concentration occurs (5). Thus, the surge in antioxidant enzyme expression may be beneficial in protecting the newborn from oxygen toxicity, especially because an equivalent increase in inspiratory oxygen concentration is lethal to adults (20).

It cannot necessarily be assumed, however, that the surge in antioxidant expression that occurs in late fetal development in other animal species occurs in the mouse. It has been reported that such a surge fails to occur in the human lung (21). Furthermore, we have been unable to find data examining the expression of Sod 1 and Gpxl in late-gestational mouse fetuses. Only one study has examined the embryonic expression of Sod 1 and Gpx 1 in the mouse liver and the remaining carcass (22). These workers report an increase in the expression of Sod 1 and Gpxl in the liver and remaining carcass during development. They have not. however, studied the expression of antioxidant enzymes in other individual organs. Thus, our data of increasing Sod 1 and Gpx 1 mRNA levels in the mouse lung at or just before birth demonstrates that the mouse is similar in this regard to other animal species. Furthermore, our data would appear to support the hypothesis that the pulmonary antioxidant system undergoes a preparation for birth. However, the process of birth cannot be the sole reason for the surge in antioxidant $\mathrm{mRNA}$ levels because we find that during organogenesis (d 14-16) the mRNA levels for Sod 1 are even higher than those at or around the time of birth. Nevertheless, if the transition from an hypoxic to hyperoxic environment is a trigger for the surge in the expression of lung antioxidant enzymes during late fetal development, then this surge should occur in all aerobic organisms where such a transition occurs. In this context, it remains to be explained why such a surge in antioxidant enzymes fails to occur in human fetuses. This explanation is especially important because it has been proposed that the failure to detoxify reactive oxygen species might be related to aspects of the oxidative-induced morbidity and mortality (e.g. bronchopulmonary dysplasia) that occurs in preterm human infants (23).

It has also been argued by others that the surge in expression of antioxidant enzymes in organs of late-gestation fetuses cannot solely be assigned to the preparation of the pulmonary antioxidant system for birth (5). This proposal was based on the finding that a similar surge in the expression of antioxidant enzymes also occurs in the livers of late-gestation guinea pig fetuses (5). The liver, unlike the lung, is not directly exposed to higher oxygen concentrations at birth. Our data in this study confirm and extend the finding of Rickett and Kelly (5) by showing that the surge in the levels of both Sod 1 and Gpx 1 occurs in the livers of mouse fetuses in late gestation, albeit that the levels for both these enzymes decline after birth in the early neonatal period. It may be that the elevation of expression of antioxidant enzymes in the liver, and the finding that the expression of the antioxidant enzymes is relatively high in adult livers, is related to the rate of metabolism of the organ rather than to the concentration of oxygen per se. Higher rates of metabolism may result in the generation of reactive oxygen species. It is also interesting that the expression of Sod 1 and Gpxl increases in the amnion during the period of organogenesis in the mouse. The amnion is a membrane that surrounds the fetus. Consequently, the elevation of expression of antioxidant enzymes in both the liver and the amnion may afford protection against the generation of reactive oxygen species in the maternal compartment.

The extension of studies on the expression of antioxidant enzymes to other organs may be useful for evaluating the purpose of the surge in antioxidant expression in organ(s) of late-gestation fetuses. The data in this study demonstrate that the elevation in expression of both Sod 1 and Gpx 1 antioxidant enzymes occurs in the liver, lung, and stomach. An elevation in Sod 1 expression, but not Gpx l, occurs in the brain of fetuses in late gestation, at birth, or both. However, the heart fails to show an appreciable elevation of both Sod 1 and Gpx 1 expression in late gestation or at birth. Yet the oxygen consumption of the heart in fetal lamb development during late gestation is far greater than that of other organs $(8.0 \mathrm{~mL} / 100 \mathrm{~g}$ of tissue). Indeed, the order of oxygen consumption by organs in late gestation lamb fetuses is heart $(8.0 \mathrm{~mL} / 100 \mathrm{~g})>$ brain $(4.0 \mathrm{~mL} / 100 \mathrm{~g})=$ liver $>$ kidney $(2.6$ $\mathrm{mL} / 100 \mathrm{~g})>$ lung $(0.6 \mathrm{~mL} / 100 \mathrm{~g})>$ intestine $(0.4 \mathrm{~mL} / 100 \mathrm{~g})=$ skin, bone, and muscle (24). Thus, the data suggest that the increase in expression of antioxidant enzymes in late gestation or at birth in organs of the mouse may not correlate with the 
oxygen tension or oxygen consumption of organs [if this finding is similar to that in the lamb, which it is presumed to be (25)]. In addition, the finding that Sod 1 and Gpx 1 mRNA levels are not temporally up-regulated in all tissues in a similar fashion further argues against the idea that the up-regulation of the antioxidant genes occurs in response to the increased oxygen consumption of specific tissues. These findings are further supported by a comparison of the relative levels of Sodl and/or Gpx 1 mRNA in different organs of the adult. The brain is the organ that consumes approximately $25 \%$ of the circulating oxygen from the blood (26), whereas the lung, of the internal organs, is exposed to the highest concentration of oxygen (27). Yet both the lung and the brain have much lower mRNA levels for the antioxidant enzymes than the liver in embryonic, neonatal. and adult mice. Thus, the organs with the highest oxygen consumption or oxygen tension do not have the highest expression of antioxidant enzymes.

It may be that the antioxidant enzymes have other functions in addition to preparation of the pulmonary system for birth and the protection of organs from free oxygen radicals. For instance, by altering the activities of Sod 1 and/or Gpxl the formation or persistence of the superoxide radical, hydrogen peroxide, or hydroxyl radical molecules may be favored. It has recently been shown that the exposure of cells to increasing amounts of hydrogen peroxide increases the binding of the NF- $\kappa \mathrm{B}$ transcription factor (28). Indeed, it has been proposed that hydrogen peroxide (and possibly other free radicals) may be second-messenger molecules affecting the proliferation and differentiation of cells (28, 29). Thus, it is conceivable that the expression of Sod 1. Gpxl, or both may also be influenced by the need for molecules resulting from the antioxidant pathway to carry out its other functions. In this regard, it is also interesting that the activity of Sod increased during differentiation of the slime mould Phisarum polycephalum (30). Furthermore, augmentation of Sod 1 via liposomes into undifferentiated $P$. polycephalum and Friend erthyroleukemia cells induced the differentiation of these cells $(31,32)$. In addition, it has been shown that the cellular environment becomes progressively more oxidized during embryonic development in the housefly $(33)$. Oberley et al. $(34,35)$ have also shown that the expression of antioxidant enzymes change in different areas of the developing Syrian hamster kidney and in organs where self-renewal occurs, thus suggesting an important role for these enzymes in cell differentiation during development and self-renewal. Thus, all these data are suggestive of other functions for these enzymes, which may influence the levels of Sodl and Gpxl in organs of the developing mouse embryo or fetus.

The molecular mechanisms whereby the expression of Sod 1 and Gpxl are up-regulated in the lung and liver of late-gestation fetuses remains to be explained. Our data demonstrate, however. that such an up-regulation occurs at the mRNA level of both genes. Whether the increase in Sod 1 and Gpx 1 mRNA is due to increased transcription of both genes or due to increased mRNA stability remains to be explained. In addition, it is important that further studies on establishing the expression patterns of Sod 1 and Gpx 1 during murine embryo development should be pursued using in situ hybridization analysis, immunohistochemistry, or both, so that differential expression by specific cell types within organs are identified.

In conclusion, this study has shown that a surge in Sod 1 and Gpx 1 expression occurs in late-gestation murine fetuses in some but not all organs. The lung, liver, and stomach are organs where such a surge occurs. In the other organs, either an elevation in Sod! or Gpxl expression alone occurs (e.g. brain and kidney respectively) or no elevation in both Sod 1 and Gpxl occurs (e.g. the heart). The data in this study suggest that the mRNA level of Sod 1 and Gpxl expression is unrelated to the oxygen consumption and to oxygen tension exposure in individual organs of late-gestational mouse fetuses and is thus suggestive of other functions for these enzymes.
Acknowledgments. The authors thank their colleagues in the Molecular Embryology and Birth Defects Laboratory for helpful discussions and critical review of the manuscript.

\section{REFERENCES}

1. Halliwell B, Gutteridge JMC 1985 Free Radicals in Biology and Medicine. Claredon Press, Oxford

2. McCord JM. Fridovich I 1969 Superoxide dismutase. An enzymatic function for erythrocuprein (hemocuprein). J Biol Chem 244:6()49-6(055

3. Weisiger RA. Fridivich I 1973 Mitochondrial superoxide dismutase. Site of synthesis and intramitochondrial location. J Biol Chem 248:4793-4796

4. Chance B. Sies H. Boveris A 1979 Hydroperoxide metabolism in mammalian organs. Physiol Rev 59:527-605

5. Rickett GMW, Kelly FJ 1990 Developmental expression of antioxidant enzymes in guinea pig lung and liver. Development 108:331-336

6. Frank L. Groseclose EE 1984 Preparation for birth into an $\mathrm{O}^{2}$-rich environment: the antioxidant enzymes in the developing rabbit lung. Pediatr Res 18:240-244

7. Tanswell AK. Freeman BA 1984 Pulmonary antioxidant enzyme maturation in the fetal and neonatal rat. I. Developmental profiles. Pediatr Res 18:584587

8. Gerdin E. Tyden O. Eriksson UJ 1985 The development of antioxidant enzymatic defence in the perinatal rat lung: activities of superoxide dismutase, glutathione peroxidase, and catalase. Pediatr Res 19:687-691

9. Frank L. Sosenko IRS 1987 Prenatal development of lung antioxidant en $2 y m e s$ in four species. J Pediatr 110:106-110

10. Sosenko IRS, Frank L 1987 Guinea pig lung development: antioxidant enzymes and premature survival in high $\mathrm{O}_{2}$. Am J Physiol 252:R693-R698

11. de Haan JB, Newman JD. Kola I $1992 \mathrm{Cu} / \mathrm{Zn}$ superoxide dismutase mRNA and enzyme activity, and susceptibility to lipid peroxidation. increases with aging in murine brains. Mol Brain Res 13:179-187

12. Chomezynski P. Sacchi N 1987 Single-step method of RNA isolation by acid guanidinium thiocyanate-phenol-chloroform extraction. Anal Biochem 162:156-159

13. Getzoff ED. Tainer JA. Stempien MM. Bell Gl. Hallewell RA 1989 Evolution of $\mathrm{CuZn}$ superoxide dismutase and the Greek key $\beta$-barrel structural motif. Proteins Struct Funct Genet 5:322-336

14. Sanger $F$. Nicklen $S$, Coulson AR 1977 DNA sequencing with chain-terminating inhibitors. Proc Natl Acad Sci USA 74:5463-5467

15. Elroy-Stein O. Bernstein $Y$. Groner $Y 1986$ Overproduction of human $\mathrm{Cu} / \mathrm{Zn}$ Superoxide dismutase in transfected cells: extenuation of paraquat-mediated cytotoxicity and enhancement of lipid peroxidation. EMBO J 5:615-622

16. Lawrence RA. Burk RF 1976 Glutathione peroxidase activity in seleniumdeficient rat liver. Biochem Biophys Res Commun 71:952-958

17. Bewley GC $1988 \mathrm{cDNA}$ and deduced amino acid sequence of murine Cu- $\mathrm{Zn}$ superoxide dismutase. Nucleic Acids Res 16:2728

18. Delabar JM. Nicole A. D'Auriol L. Jacoh Y. Meunier-Rotival M. Galibert F, Sinet PM, Jerome H 1987 Cloning and sequencing of a rat $\mathrm{CuZn}$ superoxide dismutase cDNA: correlation between $\mathrm{CuZn}$ superoxide dismutase mRNA level and enzyme activity in rat and mouse tissues. Eur J Biochem 166:181187

19. Hayashibe H. Asayama K. Dobashi K. Kato K 1990 Prenatal development of antioxidant enzymes in rat lung. kidney, and heart: marked increases in immunoreactive superoxide dismutases, glutathione peroxidase, and catalase in the kidney. Pediatr Res 27:472-475

20. McCord JM 1979 Superoxide, superoxide dismutase and oxygen toxicity. Rev Biochem Toxicol 1:109-124

21. Strange RC. Cotton W. Fryer AA. Drew R. Bradwell AR, Marshall T. Collins MF. Bell J. Hume R 1988 Studies on the expression of Cu, $\mathrm{Zn}$ superoxide dismutase in human tissues during development. Biochim Biophys Acta 964:260-265

22. El-Hage S. Singh SM 1990 Temporal expression of genes encoding free radicalmetabolizing enzymes is associated with higher $\mathrm{mRNA}$ levels during in utero development in mice. Dev Genet 11:149-159

23. Strange RC, Cotton W. Fryer AA. Jones P. Bell J. Hume R 1990 Lipid peroxidation and expression of copper-zinc and manganese superoxide dismutase in lungs of premature infants with hyaline membrane disease and bronchopulmonary dysplasia. J Clin Lab Med 116:666-673

24. Rudolph AM 1984 Oxygenation in the fetus and neonate-a perspective. Semin Perinatol 8:158-167

25. Philipps AF 1992 Carbohydrate metabolism of the fetus. In: Polin RA, Fox WW (eds) Fetal and Neonatal Physiology. WB Sanders. Philadelphia, pp 373-375

26. Fried $\mathrm{R} 1979$ Superoxide dismutase activity in the nervous system. J Neurosci Res 4:435-44i

27. Yoshioka T. Shimada T. Sekiba K 1980 Lipid peroxidation and antioxidants in the rat lung during development. Biol Neonate 38:161-168

28. Schreck R, Rieber P, Baeuerle PA 1991 Reactive oxygen intermediates as apparently widely used messengers in the activation of the NF- $\mathrm{B}$ transcription factor and HIV-1. EMBO J 10:2247-2258

29. Schulze-Osthoff K. Fiers W 1991 Oxygen radicals as second messengers. Trends Cell Biol 1:150

30. Allen RG. Newton RK, Sohal RS, Shipley GL. Nations C 1985 Alterations in superoxide dismutase, glutathione, and peroxides in the plasmodial slime 
mold Phisarum policephalum during differentiation. J Cell Physiol 125:413419

31. Allen RG. Balin AK, Reimer RJ. Sohal RS. Nations C 1988 Superoxide dismutase induces differentiation in microplasmodia of the slime mold Phy'sarum polycephalum. Arch Biochem Biophys 261:205-21

32. Beckman BS, Balin AK. Allen RG 1989 Superoxide dismutase induces differentiation of Friend erythroleukemia cells. J Cell Physiol 139:37()-376

33. Allen RG, Oberley LW. Elwell JH. Sohal RS 1991 Developmental patterns in the antioxidant defences of the housefly, Ifusca domestica. J Cell Physiol
$146: 270-276$

34. Oberley TD Oberley IW Slattery AF Lauchner LJ. Elwell JH 1990 lmmunohistochemical localization of antioxidant enzymes in adult Syrian hamster tissues and during kidney development. Am J Pathol 137:199-214

35. Oberley TD. Oberley LW. Slattery AF. Elwell JH 1991 Immunohistochemical localization of glutathione-S-transferase and glutathione peroxidase in adult Syrian hamster tissues and during kidney development. Am J Pathol $139: 355-369$

\section{Announcement}

\section{Paediatric Week Holland}

The Paediatric Week Holland will be organized in Rotterdam. The Netherlands from June 29 to July 6, 1994. From July 3 through July 6, a combined meeting will be held of the European Society for Paediatric Research, the European Paediatric Respiratory Society, the European Respiratory Society-Paediatric Assembly, the European Society of Paediatric Allergy/Clinical Immunology, the European Society for Paediatric Infectious Diseases, the European Society of Paediatric Intensive Care, and the European Society for Paediatric Hematology and Immunology. From June 29 through July 2, the British Association of Paediatric Surgeons will meet, and the Dutch Society of Psychosocial Consultation and Paediatrics will meet from July 3 through July 5. Postgraduate courses will be organized in the overlapping weekend. For further information, please contact: Pieter J. J. Sauer, M. D., c/o Erasmus University Rotterdam, P.O. Box 1738, NL-3000 DR Rotterdam, The Netherlands. 